publications of I. V. Stalin in these fields". But as regards chemistry, long experience with abstract journals has convinced the authors of the paramount need for some single but authoritative and comprehensive chemical abstract journal in the U.S.S.R., for both the theoretical and practical domains.

There is only space here to indicate the other points discussed-for example, choice of material to be abstracted, which should include not only periodicals and patents but also books, etc. (even the general press and popular magazines) ; linguistic scope of abstracts (what countries and languages, for there are already ten different languages in the Soviet Union itself); nature and value of the information provided, with critical evaluation; what the abstract should contain; and one or two miscellaneous considerations.

W. G. CASS

\section{THE TURKISH EARTHQUAKE OF MARCH 18}

$\mathrm{T}$ HE recent earthquake in Turkey was not one of the greatest of that region, but it happened in a moderately well populated area and consequently the casualties have been relatively great.

Provisional readings of the Edinburgh east-west component seismogram indicate the initial time for the earthquake as $20 \mathrm{hr} .06 \mathrm{~m}$. 16 s. G.M.T. The epicentre appears to have been near Çan in the province of Canakkale, Western Anatolia (lat. $40^{\circ}$ N., long. $27^{\circ}$ E.), and the depth of focus normal. The Edinburgh Milne-Shaw seismograph has a magnification of 250, and the maximum surface waves, which are pronounced in this shock, measure $7.1 \mathrm{~cm}$. amplitude (mean to extreme) on the record.

The earthquake was experienced chiefly in the Provinces of Chanakkale and Balikesir, bordering the Agean Sea, and south of the Dardanelles. The area between Yenice and Gonen suffered severely. In this district more than six hundred houses were destroyed and many more were damaged; fire added to the damage. Can is a centre of routes in the area, the railway lines from Çan going respectively south-east to Baya, north-north-east to Biga and Karabiga and west-north-west to Çanakkale. All these communications were interrupted and telephone and telegraph lines were down. Reports from fifty-seven villages in the epicentral area were still awaited two days after the earthquake. The shock was felt in Istanbul as strongly as any earthquake since 1906, and some apprehension was felt. Some buildings were damaged in Istanbul, including the Dolmabagtche Palace, where walls cracked and plaster fell off the ceiling of the famous reception hall. Damage has been reported from the Aggean Islands of Chios and Lesbos and the tremor was felt throughout northern Greece. 'The full list of damage and casualties cannot yet be assessed, but reported damage two days after the event is estimated at a quarter of a million pounds sterling, deaths at more than five hundred and injured at more than a thousand. Ankara observatory reported sixty-five aftershocks on March 19 and fourteen more to noon on March 20.

In Turkey there are annually some hundred to hundred and fifty earthquakes which are felt but which do no damage. Some others do damage only in the immediate vicinity of their epicentres; but since 1938, excluding the present shock, there have been thirteen disastrous earthquakes. These have been: (a) in Central Anatolia-Kirsehir-Yerköy, 1938 (19 Nisan 1938 Orta Anadolu yer deprenmesi. Ed. Paréjas and Hamit N. Pamir. Istanbul Ūniversitesi Jeoloji Enstitūsū Nesriyati, No. 5, 1940); (b) in Septrionale Anatolia-Erzincan (magnitude 8), December 27, 1939 (27 Birinci Kânun 1939 Erzincan yerdepremi. Ed. Parejas, I. H. Akyol, E. Altinli. I.U.J.E.N., No. 10, 1942, also Nature, January 6, 1940), Erbaa-Osmancik (magnitude 7.5) 1942, Adapazari 1943, Amasya-Tosya (magnitude 7.5) 1943, Bolu-Gerede (magnitude 7.5) 1944, (c) in south-east Anatolia, Ceyhan-Misis 1945, Van 1945, Varto 1946, Bingöl 1949; and $(d)$ in the AEgean area in which the present epicentre is situated, Dikili 1939, Ayvacik 1944 and Çesme-Karaburun 1949. In the course of these thirteen earthquakes, fifty thousand people have been killed and a hundred thousand houses destroyed or seriously damaged. Since 1938 earthquake damage has probably cost the Turkish people 100 millions of Turkish pounds.

Tectonically, the area around the Marmara basin consists of faulted synclines, and the area adjoining the Agean Sea consists of faulted depressions. In between these synclines or depressions there are anticlines with palæozoic cores, 'plis de fond' or 'massifs'. The elements have been orogenically active throughout geological time, but since the end of the Néogène the general movement has been an upward (epirogenic) one. This rise is shown by the altitude of Néogène lacustrine deposits and by the quaternary terraces. To-day it is still continuing and is evidenced by the sudden changes of equilibrium between sections with faulted contact. Earthquakes accompany the faulting.

ERNEST TILLOTSON

\section{THORNTHWAITE FOREST, CUMBERLAND}

$T$

HORNTHWAITE was one of the first forests to be established by the Forestry Commission in Cumberland, which took over eleven hundred acres of land around the Whinlatter Pass in 1920 and began planting the same year. Other land has been added from time to time, the latest acquisition being in 1947, and, since planting has proceeded continually, all ages of trees up to thirty-two years are represented. A short record of this forest has now been published by the Forestry Commission in a booklet entitled "Britain's Forests-Thornthwaite"*. The bulk of the work on the larger sections--Whinlatter, Wythrop and Dodd-was finished by 1931, and thus most of the plantations are more than twenty years old. Formerly, the young trees for planting were raised at a small forest nursery near Thornthwaite village; but nowadays they are brought from larger nurseries near the Scottish border. The forest lies three miles from Keswick, two and a half miles from Cockermouth, and twenty-three miles from Carlisle. Its greatest length from north to south is seven miles, and its greatest breadth six miles, including outlying plantations. The distance around Bassenthwaite Lake by road, which touches on most of the plantations, is eighteen miles.

Soon after the Commission commenced planting in the beautiful Lake District, there was a considerable

* Forestry Commission. Britain's Forests-Thornthwaite. Pp. 20. (London: H.M.S.O., 1952.) 18 . net. 
outcry-almost inevitable, since the objectives of forestry are little appreciated in Britain. Such forestry as existed in the country a couple of centuries ago was confined to hardwoods; for many reasons, much of the Cumberland hills were only suitable for conifers.

There are many aspects from which Thornthwaite may be examined. Perhaps one of the best known is from the south. As one approaches the well-known town of Keswick by way of the main road from Ambleside, a beautiful panorama is unfolded which includes the young forest, now covering five thousand acres. About two and a half miles short of Keswick, Bassenthwaite is seen below with the young plantations of spruce, pine and larch on the hills on either side with, at the back on the far side, Skiddaw rising to $3,053 \mathrm{ft}$.

The forest is divided into several sections bearing the local names of the areas concerned, the latest plantations dating from 1948 and 1950. The kinds of trees used are the spruces, Sitka and Norway, Scots pine, and, in small amount, Pinus contorta and $P$. mujo, with Douglas fir, Lawson's cypress and western red cedar. On the bottom soils and in sheltered places Japanese larch is planted. Curiously enough, the European larch does not do well in this region. More latterly, the Commission has been planting amenity belts along the Bassenthwaite roads to break the monotony of the dark conifers. The belts include the American red oak, beech, wild cherry, western red cedar, ash, birch and maple, which are seen at their best in the spring and autumn. Thinnings are being made in the older woods, from the poles of which pitprops and finer stakes are yielded, providing a return from the forest and providing work for a considerable labour force.

E. P. Stebing

\section{NATIONAL PARKS IN GREAT BRITAIN}

\section{T} HE third annual report of the National Parks Commission* covers the year ended September 30,1952 , and notes the confirmation of the Designation Orders for Snowdonia, Dartmoor and Pembrokeshire coast national parks, and the designation, on February 12, 1952, of a sixth area, the North York moors, as well as consultations with local authorities coneerning a proposed Cornish National Park. It records the view that, in spite of unpropitious economic circumstances, the design of the National Parks Act is taking shape. The claim that substantial advance has been made, however, scarcely seems to be justified by the contents of the report, although it appears that, with the exception of Snowdonia, the park authorities, in spite of handicaps due to economic circumstances, have been working with some promise and that the problems of each park are being studied by each authority with a full and proper appreciation of the intentions of the National Parks Act. The tale of administrative difficulty due to ministerial faithlessness, and the persistence of misconceptions as to the effect of designation of areas as national parks on access, is repeated from the previous report; and although the references to financial difficulties are more

* National Parks and Access to the Countryside Act, 1949. Third Report of the National Parks Commission for the Year ending 30th oblique than in the second report of the Commission there is no substantial evidence in the present report of the disappearance of the parsimony which was last year reported as hindering its educational work through the distribution of the proposed leaflet on the Country Code.

Nothing is said about that leaflet in the present report, and, although the education authorities have rendered much assistance in making the Country Code widely known to the youth of the country, it may be inferred that the Commission's own proposal is still frustrated. The most hopeful features of the report are, in fact, to be found, first, in the evidence it provides of widespread co-operation and goodwill, and, second, in the determination with which the Commission has maintained its position in the face of official indifference.

On the first, directors of education, the Railway Executive, the London Transport Executive and the Central Office of Information have helped to make the Country Code widely known, while much help has been received from local authorities, the Peak Planning Board, the Youth Hostels Association, the Ramblers' Association, the County Councils of Cornwall, Devon, Dorset and Somerset, and individual ramblers at one or more of the numerous stages-from preliminary survey to the erection of cairns and stakes or the provision of hostel accommodation involved in the establishment of the projects for long-distance routes, such as the Pennine Way, now at an advanced stage, the Cornish North Coast Path, the Pembrokeshire Coastal Path, the Thames Riverside Walk, the South Downs route and the Pilgrim's Way. The extent of such co-operation fully justifies the Commission's claim that "the designation, progressively; of the finest areas of England and Wales as National Parks signifies public recognition of the supreme quality of our landscape and of its permanent importance as a factor in the moral and physical welfare of our people, and of the need on that account to ensure that it passes inviolate to future generations". Nevertheless, such public recognition is incomplete, and whether, in fact, the long-term ideal, of which the National Parks and Access to the Countryside Act is the practical expression, is to be realized depends largely on the success of the Commission's stand in regard to administration, and the extent to which the Commission is supported in a matter which, the Commission reiterates, "is of pivotal importance not only to each individual Park but to National Parks policy as a whole".

For this reason the Commission has appended to the present report details of the administrative arrangements for the Peak District, the Lake District, the Dartmoor and the Pembrokeshire Coast National Parks. Closer acquaintance with the practical problems has only confirmed the Commission in the view it has held most strongly from the start, and which has been held by all others before it who have studied this problem-namely, that, short of an organization such as was contemplated by the Hobhouse Committee, the joint planning board, with its own whole-time planning staff, is the most appropriate and serviceable admiristrative instrument. Such a joint planning board should have at least a whole-time planning officer, who should be a servant of the board and independent of any of the component local authorities. The Commission regards this as a corollary to the principle that a national park should be treated as an integral unit, planned by a single authority with 